\title{
Characterization of Porous $\beta$-Tricalcium Phosphate Films Formed on Alumina Ceramics by Spray-Pyrolysis Technique and Their in vitro Evaluations Using Osteoblasts
}

\author{
Mamoru AIZAWA, Kiyoshi ITATANI* and Isao OKADA* \\ Department of Industrial Chemistry, Faculty of Science and Engineering, Meiji University, \\ 1-1-1, Higashimita, Tama-ku, Kawasaki-shi 214-8571 \\ *Department of Chemistry, Faculty of Science and Engineering, Sophia University, 7-1, Kioi-cho, Chiyoda-ku, Tokyo 102-8554
}

\author{
噴霧熱分解法によりアルミナセラミックス上に形成させた多孔質 $\boldsymbol{\beta}$-リン酸三カルシウム膜の \\ キャラクタリゼーション及び骨芽細胞を用いた in vitro 評価 \\ 相澤 守·板谷清司*·岡田 勲* \\ 明治大学理工学部，214-8571 神奈川県川崎市多摩区東三田 1-1-1 \\ *上智大学理工学部，102-8554 東京都千代田区紀尾井町 7-1
}

\begin{abstract}
Porous calcium-phosphate films were formed on alumina ceramics by a spray-pyrolysis technique, using two kinds of starting solutions having $\mathrm{Ca} / \mathrm{P}$ ratios of 0.50 and 1.67. A $\beta$-tricalcium phosphate $(\beta$-TCP) phase was present in the resulting films with a thickness of about $50 \mu \mathrm{m}$. The films were porous and the median pore size was about $105 \mu \mathrm{m}$. After $\operatorname{Scotch}^{\circledR}$ tape $(\# 810)$ adhering to the films was removed from the substrates, the films were still present on the substrate. The biocompatibility of the alumina ceramics coated with $\beta$-TCP (simply referred to as coated specimen) was examined using MC3T3-E1 cells as an osteoblast model. The cells on the coated specimen well proliferated in a similar manner to those cultured polystyrene dish and on uncoated alumina ceramics. The alkaline phosphatase activity of the cells cultured on the coated specimen for $17 \mathrm{~d}$ was significantly higher than that of the uncoated alumina ceramics. The present porous $\beta$-TCP films have good cellular responses with respect to cell proliferation and differentiation.
\end{abstract}

[Received October 4, 2004; Accepted December 15, 2004]

Key-words : $\beta$-tricalcium phosphate, Spray-pyrolysis technique, Coating, Porous films, Biocompatibility, Cell culture, Osteoblasts, in vitro evaluation

1. Introduction

Hydroxyapatite $\left(\mathrm{Ca}_{10}\left(\mathrm{PO}_{4}\right)_{6}(\mathrm{OH})_{2} ; \mathrm{HAp}\right)$ and $\beta$-tricalcium phosphate $\left(\beta\right.$ - $\mathrm{Ca}_{3}\left(\mathrm{PO}_{4}\right)_{2} ; \beta$-TCP) have excellent biocompatibility and are used as substitute materials for human hard tissues. ${ }^{1)}$ However, the mechanical strength, especially the fracture toughness and Young's modulus, of these ceramics are inferior to those of natural bone and teeth. ${ }^{2)}$ Thus, it is difficult to use the HAp or $\beta$-TCP ceramics in the load-bearing parts of the human body. In order to improve the mechanical strength, much attention has been devoted to fabrication of a composite material of calcium phosphate either with various metals such as Ti alloys ${ }^{3)}$ or with high-strength ceramics such as alumina ${ }^{4)}$ and zirconia ceramics. ${ }^{5)}$

Many researchers have attempted to create composite materials possessing both excellent mechanical strength and biocompatibility by forming calcium-phosphate films on metal rods or on high-strength ceramics. They have proposed various coating processes as follows: sputtering, ${ }^{6}$ electrophoresis, ${ }^{7)}$ biomimetic coating using the $\mathrm{MgO}-\mathrm{CaO}-\mathrm{SiO}_{2}-\mathrm{P}_{2} \mathrm{O}_{5}-$ $\mathrm{CaF}_{2}$ glass and the simulated body fluid, ${ }^{8)}$ plasma spray, ${ }^{9)}$ and dipping-pyrolysis. ${ }^{10)}$ Most of these processes are suitable for the formation of dense films, but not porous films.

The porous calcium-phosphate films, where the pores are utilized as formation sites of new bone, can be formed by the spray-pyrolysis technique. ${ }^{11)-17)}$ We have previously reported that the porous $\beta$-TCP and/or HAp films were formed by spray pyrolysis on various high-strength ceramics, i.e., alumina ceramics, ${ }^{11)-13)}$ yttria-stabilized tetragonal zirconia ${ }^{14), 15)}$ and nanocomposite of ceria-stabilized tetragonal zirconia with alumina. ${ }^{16)}$ This spray-pyrolysis technique for the formation of films is especially effective for controlling both the composition and morphology of the resulting films; one can easily form porous films having a three-dimensional (3D) framework structure. ${ }^{17)}$ In addition, by this technique calciumphosphate films can be coated even on a substrate with a wide area and in a complex shapes.

However, we have not yet clarified some properties, such as the mechanical strength, the microstructure, including the pore size distribution of the porous films, and the biocompatibility of calcium-phosphate films formed on the abovementioned ceramics by the spray-pyrolysis technique. Thus, we took notice especially of the calcium-phosphate films formed on alumina ceramics, because alumina ceramics are well known as the most important bioinert ceramics. The main purposes of the present investigation were to (i) examine some properties of the $\beta$-TCP films formed on alumina ceramics by spray-pyrolysis and (ii) to evaluate the biocompatibility of the resulting films in vitro, using MC3T3-E1 cells as an osteoblast model. ${ }^{18)}$ Our findings may give the field of biomaterials new information on the coating of bioceramics.

\section{Experimental}

2.1 Fabrication of alumina ceramics coated with calcium phosphate

Two kinds of starting solutions having $\mathrm{Ca} / \mathrm{P}$ ratios of 0.50 and 1.67 were prepared by mixing $\mathrm{Ca}\left(\mathrm{NO}_{3}\right)_{2},\left(\mathrm{NH}_{4}\right)_{2} \mathrm{HPO}_{4}$ and $\mathrm{HNO}_{3}$, which correspond to the compositions of calcium metaphosphate $\left(\mathrm{Ca}\left(\mathrm{PO}_{3}\right)_{2} ; \mathrm{CMP}\right)$ and of HAp, respectively. 
These solutions will be referred to as "the CPM solution" and "the HAP solution", respectively. Table 1 gives the compositions of the starting solutions.

The alumina ceramics used as the substrate were prepared by firing the compressed powder at $1300^{\circ} \mathrm{C}$ for $5 \mathrm{~h}$ with a heating rate of $10^{\circ} \mathrm{C} \cdot \mathrm{min}^{-1}$. Commercially available $\alpha$-alumina powder (Taimei Kagaku, TM-DAR) was used as the starting material. The relative density of the resulting ceramics as the substrate was about $95 \%$ of the theoretical density.

The spray-pyrolysis apparatus used for the calciumphosphate coating was previously reported in detail. ${ }^{11)-17)}$ The substrate was fixed by a clip in the upper part of the reaction tube; the substrate temperature was about $220^{\circ} \mathrm{C}$. The calcium-phosphate films were formed on the alumina ceramics, as shown in Fig. 1. The films consisting of the CMP and HAp were first deposited on the alumina ceramics by spray-pyrolysing the CPM solution as the starting solution for $5 \mathrm{~h}$ and then the HAp solution for 5,10 or $15 \mathrm{~h}$. The samples were then heated to $1200^{\circ} \mathrm{C}$ for $5 \mathrm{~h}$ in air with a heating rate of $10^{\circ} \mathrm{C}$. $\min ^{-1}$. The CMP solution was used to form the binder between calcium-phosphate films and alumina ceramics. The spray-pyrolysis temperature was fixed at $600^{\circ} \mathrm{C}$; the air flow rate for spraying the solutions was $10 \mathrm{dm}^{3} \cdot \mathrm{min}^{-1}$.

2.2 Evaluation of some properties of the alumina ceramics coated with calcium phosphate

The crystalline phases of the calcium-phosphate films formed by the above process were examined using a thin film X-ray diffractometer (TF-XRD; $40 \mathrm{kV}, 40 \mathrm{~mA}$; RINT2000 $\mathrm{PC}$, Rigaku, Tokyo). The incident angle, $\theta$, was fixed at $3^{\circ}$. The surfaces and cross sections of the resulting films were observed by a scanning electron microscope (SEM; S-4500, Hitachi, Tokyo). The thickness of the films was evaluated from the scales equipped to these SEM micrographs. The adhesion property of the films to the substrates was checked by a tape test, ${ }^{19)}$ using $\operatorname{Scotch}^{\circledR}$ tape $(\# 810)$. The pore-size distribution of the alumina ceramics coated with calcium phosphate was examined using a mercury porosimeter. The sample was set in the cell for the measurement after the resulting material $(\sim 2.8 \mathrm{~g}, 31 \mathrm{~mm} \phi \times 1 \mathrm{~mm})$ was crushed into small pieces. The mechanical strength of the alumina ceramics coat-

Table 1. Preparation of the Starting Solution for the Formation of Calcium-Phosphate Films

\begin{tabular}{|c|c|c|c|c|}
\hline & $\mathrm{Ca} / \mathrm{P}$ ratio & $\frac{\mathrm{Ca}\left(\mathrm{NO}_{3}\right)_{2}}{\mathrm{~mol} \cdot \mathrm{dm}^{-3}}$ & $\frac{\left(\mathrm{NH}_{4}\right)_{2} \mathrm{HPO}_{4}}{\mathrm{~mol} \cdot \mathrm{dm}^{-3}}$ & $\frac{\mathrm{HNO}_{3}}{\mathrm{~mol} \cdot \mathrm{dm}^{-3}}$ \\
\hline CMP solution & 0.50 & 0.75 & 1.50 & 2.0 \\
\hline HAp solution & 1.67 & 0.50 & 0.30 & 0.4 \\
\hline
\end{tabular}

ed with calcium phosphate was determined by a three-point bending test, using 6-7 specimens for each test. The crosshead speed was $0.5 \mathrm{~mm} \cdot \mathrm{min}^{-1}$ and the span was $30 \mathrm{~mm}$. The dimensions of the specimen for the bending test were $4.2 \times 3.5$ $\times 37 \mathrm{~mm}^{3}$.

\subsection{Evaluation of biocompatibilities by cell-culture tests \\ 2.3.1 Cell culture}

The cell used in the present investigation was the osteoblastic MC3T3-E1 cell line. ${ }^{18), 20)}$ The cell culture was tested using the following three kinds of specimens: (i) control (6-wells plate for the cell culture; polystyrene), (ii) alumina (alumina ceramics without coating) and (iii) coated specimens, that is, alumina ceramics with calcium-phosphate films, which were formed by spraying the CMP solution and the HAp solution for $5 \mathrm{~h}$ and $15 \mathrm{~h}$, respectively, and then by heating at $1200^{\circ} \mathrm{C}$ for $5 \mathrm{~h}$, as mentioned above. These specimens for the cell culture were disk-shaped, measuring $31 \mathrm{~mm}$ in diameter and $\sim 1 \mathrm{~mm}$ in thickness. The cells of $15 \times 10^{4}$ (cell density, $5 \times$ $10^{4} / \mathrm{cm}^{3} ; 3 \mathrm{~cm}^{3}$ ) were seeded on the three kinds of specimens to examine the following cell activities: (i) initial cell-attachment efficiency, (ii) cell proliferation, (iii) alkaline phosphatase (ALP) activity normalized for DNA assay and (iv) cell morphology. The cells were cultured in the $\alpha$-MEM $(+)$ at $37^{\circ} \mathrm{C}$ under air containing $5 \% \mathrm{CO}_{2}$, where the $\alpha-\operatorname{MEM}(+)$ is $\alpha$-minimum essential medium ( $\alpha$-MEM) containing $10 \%$ fetal bovine serum (FBS).

\subsubsection{Initial cell-attachment efficiency}

The cells were seeded on the above-mentioned three kinds of specimens in culture for $5 \mathrm{~h}(n=8$ for each specimen $)$. After cell culture, the attached cells were removed from the specimens by trypsinization using $0.25 \%$ trypsin in phosphate buffer saline $(\operatorname{PBS}(-))$, and the cell number was counted using a Burker-Turk hemoytometer. On the basis of the resulting cell number, the initial cell-attachment efficiency, $A$, was determined by

$$
A=\frac{N_{5} / N_{0}}{N_{5}^{\text {control }} / N_{0}^{\text {control }}}
$$

where $N_{0}$ and $N_{5}$ are the numbers of the cells seeded initially on the specimen and those after the culture of $5 \mathrm{~h}$, respectively; $N_{0}^{\text {control }}$ and $N_{5}^{\text {control }}$ are the corresponding numbers on the control, respectively.

\subsubsection{Cell proliferation}

Cells were seeded on the three kinds of specimens and cultured for $1,3,5$ or $7 \mathrm{~d}$ ( $n=4$ for each specimen). After cell culture, the attached cells were removed from the specimens by trypsinization to count the cell number using a BurkerTurk hemoytometer, in a similar manner to the initial cellattachment efficiency.

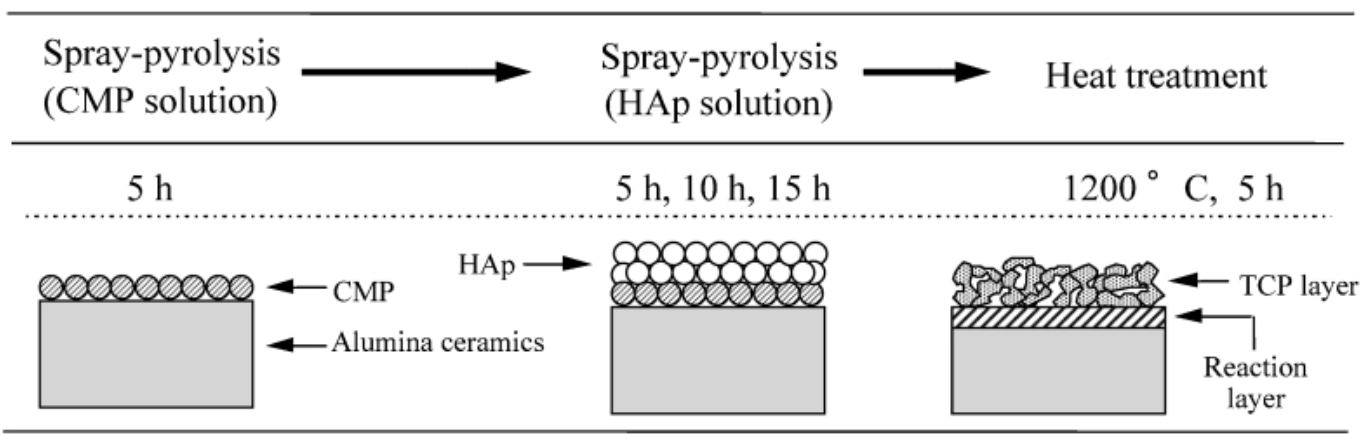

Fig. 1. Formation process of porous calcium-phosphate films by spray-pyrolysis technique. 


\subsubsection{Evaluation of alkaline phosphatase activity normal-} ized for DNA assay

After the cells seeded on the three kinds of specimens were cultured for $17 \mathrm{~d}$ ( $n=8$ for each specimen), the attached cells were removed from the specimens by the enzyme treatment using $0.1 \%$ actinase-containing $\operatorname{PBS}(-)$. The removed cells were washed three times in $20 \mathrm{mmol} \cdot \mathrm{dm}^{-3} \mathrm{~N}$-2-hydroxyethylpiperazine- $N^{\prime}$-2-ethanesulfonic acid (HEPES) buffer. The cells suspended in $1 \mathrm{~cm}^{3}$ HEPES buffer were homogenized by sonication while cooled in ice, and then centrifuged at 10000 r.p.m. for $3 \mathrm{~min}$. The resulting supernatants were used for the measurement of (i) ALP activity and (ii) DNA assay.

The ALP activity was determined using the measurement kit, ALP-test Wako ${ }^{21}$ (Wako, Japan). The DNA assay was determined by a fluorometric method using Hoechst 33258 dye. The fluorescent emission was read at $450 \mathrm{~nm}$, with an excitation of $360 \mathrm{~nm}$. A series of the standard samples, $0,0.5$, $1.25,2.5,5,10$ and $25 \mu \mathrm{g} \cdot \mathrm{cm}^{-3}$ were prepared by dissolving the DNA derived from salmon sperm (purity over 96\%) into $20 \mathrm{mmol} \cdot \mathrm{dm}^{-3}$ HEPES buffer.

\subsubsection{Observation of cell morphology}

The cells attached to the specimens were rinsed twice with PBS $(-)$ and then fixed using 10\% glutaraldehyde containing $\operatorname{PBS}(-)$ at $4^{\circ} \mathrm{C}$ for $1 \mathrm{~h}$. After washing with pure water, the fixed cells were lyophilized and then sputter-coated with $\mathrm{Pt}(80 \%)-\mathrm{Pd}(20 \%)$. The cell morphology was observed using a scanning electron microscope (SEM; Hitachi, S-4500).

\subsection{Statistical analysis}

The resulting data of the cell culture were analyzed for the statistical significance using an analysis of variance (ANOVA). Differences at $p$ values of less than 0.05 were considered to be significant. The error bars in the figures refer to the standard deviations.

\section{Results and discussion}

3.1 Characterization of the alumina ceramics coated with calcium phosphate

The crystalline phases of the resulting films on the alumina ceramics were examined by TF-XRD. Figure 2 shows the TF-XRD pattern of the films formed on the alumina ceramics by spray-pyrolysis of the CMP solution for $5 \mathrm{~h}$ and subsequently that of the HAp solution for $15 \mathrm{~h}$ and then by heating at $1200^{\circ} \mathrm{C}$ for 5 h. $\beta$-TCP was present in the resulting films, together with aluminum orthophosphate $\left(\mathrm{AlPO}_{4}\right)$ and alumina $\left(\alpha-\mathrm{Al}_{2} \mathrm{O}_{3}\right)$ ascribed to the substrate. The XRD peak of $\beta$ TCP slightly shifted toward higher Bragg angles. The films formed by spray-pyrolysis of the HAp solution for 5 and $10 \mathrm{~h}$ also consisted of $\beta$-TCP, $\mathrm{AlPO}_{4}$ and $\alpha-\mathrm{Al}_{2} \mathrm{O}_{3}$.

The formation of $\mathrm{AlPO}_{4}$ in the films may be due to the reaction of $\mathrm{P}_{2} \mathrm{O}_{5}$ in the $\mathrm{CMP}\left(\mathrm{CaO} \cdot \mathrm{P}_{2} \mathrm{O}_{5}\right)$ as a binder with $\alpha-\mathrm{Al}_{2} \mathrm{O}_{3}$ as a substrate, as given by

$$
\mathrm{Al}_{2} \mathrm{O}_{3}+\mathrm{P}_{2} \mathrm{O}_{5} \longrightarrow 2 \mathrm{AlPO}_{4}
$$

It is well known that $\beta$-TCP is transformed to $\alpha$-TCP in the range of $1120^{\circ} \mathrm{C}$ to $\left.1180^{\circ} \mathrm{C} .{ }^{22)}, 23\right)$ However, the $\beta$-phase of TCP was still present in the films after heating at $1200^{\circ} \mathrm{C}$ for $5 \mathrm{~h}$. This is presumably because the $\beta$-phase of TCP was stabilized by the solid solution of $\mathrm{AlPO}_{4}$ into TCP, as previously reported by Monma and Kanazawa. ${ }^{24)}$ In addition, the solid solution of $\mathrm{AlPO}_{4}$ into TCP could be substantiated by the shift of the $\beta$-TCP peaks to higher Bragg angles.

Figure 3 shows the SEM micrographs of the surfaces and the cross sections in the resulting $\beta$-TCP film formed on the

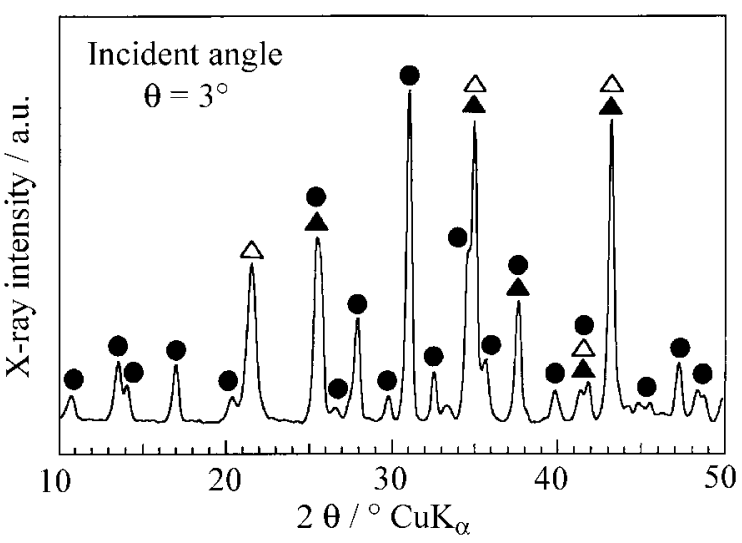

Fig. 2. TF-XRD pattern of the calcium-phosphate film formed by the spray-pyrolysis of the CMP solution for $5 \mathrm{~h}$ and the HAp solution for $15 \mathrm{~h}$, which was followed by heating at $1200^{\circ} \mathrm{C}$ for $5 \mathrm{~h}$

$\beta$-TCP, $\Delta \alpha-\mathrm{Al}_{2} \mathrm{O}_{3}, \triangle \mathrm{AlPO}_{4}$

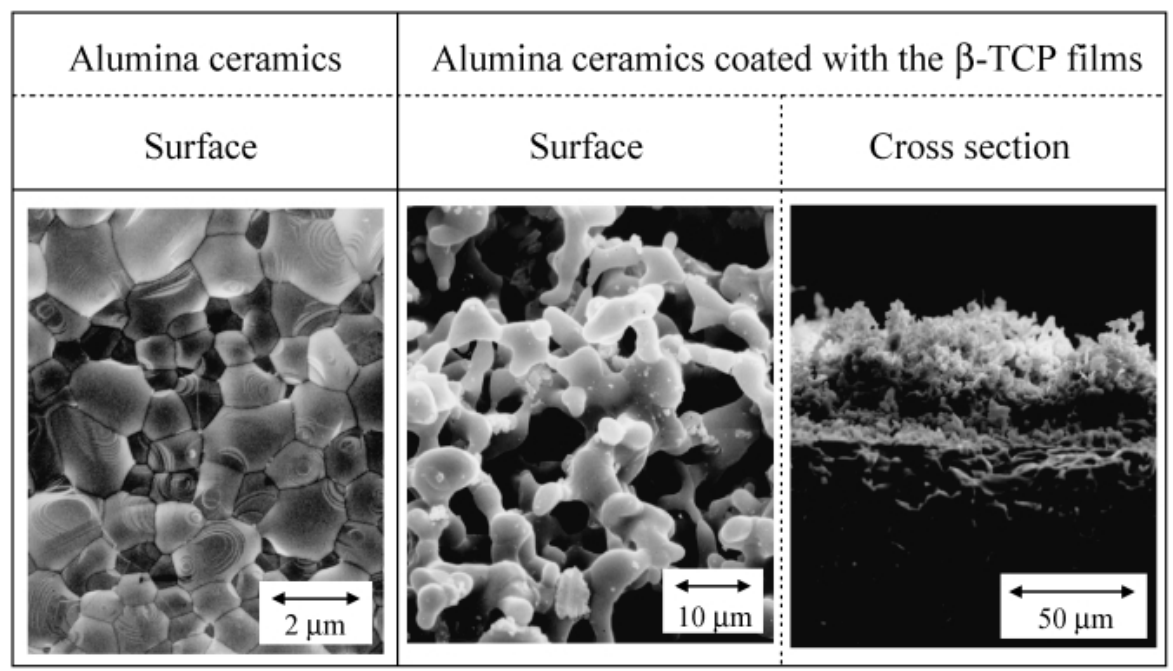

Fig. 3. SEM micrographs for the surfaces and the cross sections in $\beta$-tricalcium phosphate film formed on the alumina ceramics, together with the microstructure of the alumina ceramics without coating. Spray-pyrolyses conditions: the CMP solution for $5 \mathrm{~h}$ and the HAp solution for $15 \mathrm{~h}$. Heating conditions: $1200^{\circ} \mathrm{C}, 5 \mathrm{~h}$. 

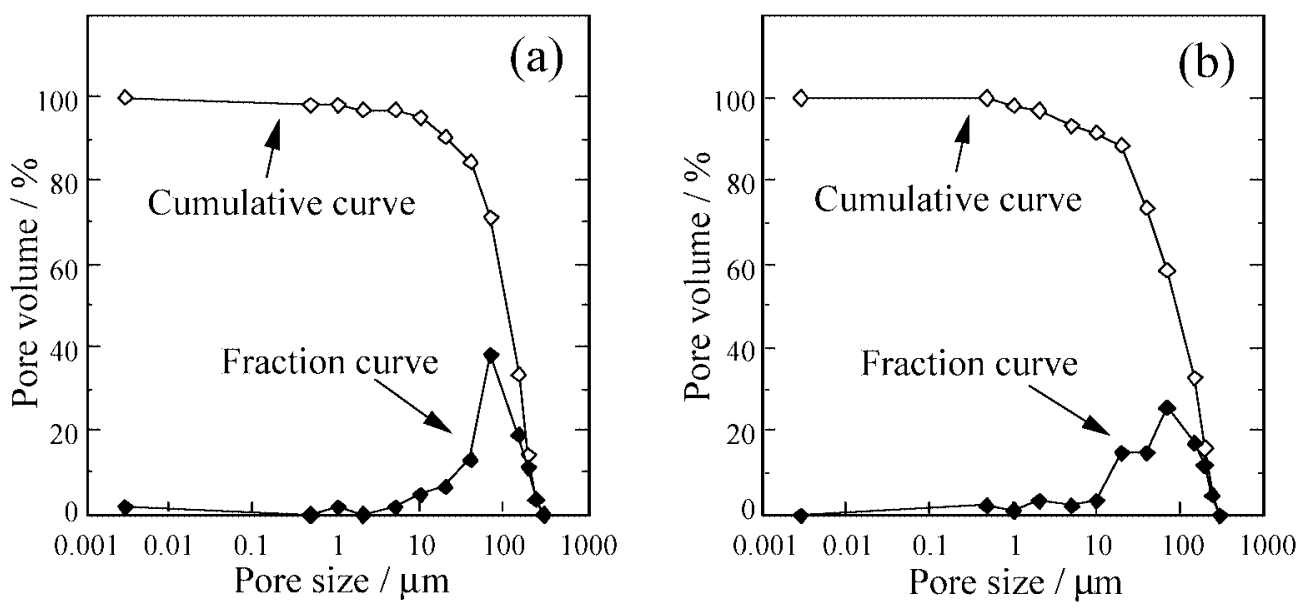

Fig. 4. Pore-size distribution of the porous $\beta$-tricalcium phosphate films. Spray-pyrolyses conditions: the CMP solution for 5 h, and then the HAp solution for $10 \mathrm{~h}$ (a) and $15 \mathrm{~h}$ (b). Heating conditions: $1200^{\circ} \mathrm{C}, 5 \mathrm{~h}$.

alumina substrate, together with the microstructure of the alumina ceramics without coating. This specimen was fabricated by spray-pyrolysing the HAp solution for $15 \mathrm{~h}$. In both surfaces of alumina ceramics coated with and without $\beta$-TCP, porous films with a 3D-framework were observed to form on the alumina ceramics which consisted of grains of $1-2 \mu \mathrm{m}$. The pore sizes of the resulting films were about $15 \mu \mathrm{m}$, while the thickness of the porous films was about $50 \mu \mathrm{m}$. The film thickness could be controlled by changing the spraying time of the HAp solution.

The formation of such pores may be due to the connection of individual particles during sintering. Generally, the powder derived from a spray-pyrolysis technique is composed of spherical hollow particles. ${ }^{25), 26)}$ Particles deposited on the substrate rapidly shrank to generate pores of $\sim 15 \mu \mathrm{m}$ during the sintering at $1200^{\circ} \mathrm{C}$ for $5 \mathrm{~h}$, as reported previously. ${ }^{11)-17)}$ Such porous films may be effective as a scaffold for the formation of new bone.

The pore size distribution of the resulting films was examined using a mercury porosimeter. The results are shown in Figs. 4(a) and (b), which correspond to the porous films formed by spraying the HAp solution for $10 \mathrm{~h}$ and $15 \mathrm{~h}$, respectively. The median pore sizes of the resulting films were determined from those cumulative curves to be $\sim 117 \mu \mathrm{m}$ for $10 \mathrm{~h}$ and $\sim 105 \mu \mathrm{m}$ for $15 \mathrm{~h}$; the former was appreciably larger than the latter, which indicates that the film may be slightly densified with increasing spray-pyrolysis time.

It should be mentioned that the pore sizes thus measured by mercury porosimetry are apparently larger than those observed by SEM. The present porous framework structure is formed by the shrinkage of spherical hollow particles on the substrate and then by the interconnection of individual particles during sintering. Whereas such porous structure is observed only from the top view on the SEM observation, pores are actually interconnected three-dimensionally; this may be the reason for this discrepancy.

Klawitter ${ }^{27)}$ has classified the pore sizes required for bone ingrowth into the pores of ceramics into the following three ranges: (i) $\sim 100 \mu \mathrm{m}$ over for the formation of calcified bone, (ii) $40-100 \mu \mathrm{m}$ for osteoids and (iii) $5-15 \mu \mathrm{m}$ for infiltration of collagen fibers and corpuscles. The median pore size of the present films satisfies the conditions for ingrowth of calcified bone into porous ceramics. Thus, the present spray-pyrolysis process will be very effective for the formation of porous films and their ability to allow bone ingrowth.

The adhesive strength of the films to the substrates was examined by a tape test. ${ }^{19)}$ When a tape adhered to the films was removed from the substrates, the films were still present on the substrate. In the case of the films formed without using the CMP solution, however, the films were easily removed from the substrate, as previously reported. ${ }^{11)}$

The bonding strength of the films to the substrates may have been improved by the presence of calcium metaphosphate $\left(\mathrm{Ca}\left(\mathrm{PO}_{3}\right)_{2}\right)$ formed by the spray-pyrolysis of the CMP solution. The products formed by spray-pyrolysis of the CMP solution, mainly calcium metaphosphate, melted during heating at $1200^{\circ} \mathrm{C}$ to react with the alumina of the substrate, leading to formation of $\mathrm{AlPO}_{4}$. This $\mathrm{AlPO}_{4}$ may act as an adhesive between the resulting films and alumina substrate. On the other hand, calcium diphosphate is partly formed from the product derived from the CMP solution during heating, and then the resultant reacted with the products formed by spraypyrolysis of the HAp solution, mainly HAp, to form the TCP. In addition, the solid solution of the $\mathrm{AlPO}_{4}$ into the TCP occurs, leading to the stabilization of the $\beta$-TCP structure.

Figure 5 shows the bending strengths of the alumina ceramics coated with and without calcium-phosphate films. These specimens were fabricated by the spray-pyrolysis of CMP solution for $5 \mathrm{~h}$ and HAp solutions for 5,10 or $15 \mathrm{~h}$, and then by heating at $1200^{\circ} \mathrm{C}$ for $5 \mathrm{~h}$. The bending strengths of the three kinds of alumina ceramics with calcium phosphate were about $300 \mathrm{MPa}$, which were almost the same as that of the uncoated alumina ceramics. No significant difference was recognized among the specimens by an ANOVA test. These results suggest that the bending strengths of alumina ceramics coated with calcium phosphate depend on the alumina substrate.

3.2 In vitro evaluation of the porous $\beta$-tricalcium phosphate films

We examined the biocompatibility of the porous $\beta$-TCP films formed on the alumina ceramics using the MC3T3-E1 cells. Figure 6 shows the relative initial cell-attachment efficiency of the cells cultured on the three kinds of specimens: (i) control, (ii) alumina ceramics and (iii) alumina ceramics coated with calcium phosphate (which will be hereafter referred to as the coated specimen). The relative initial cell-attachment efficiencies were $61 \pm 8 \%$ in the alumina ceramics and $18 \pm 3 \%$ in the coated specimens with reference to the control at $100 \%$. These results could be regarded as significant $(p$ 


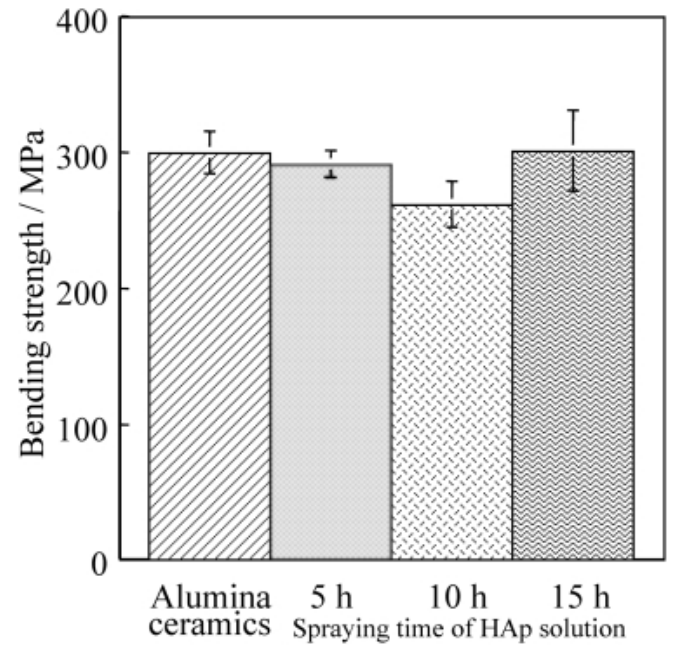

Fig. 5. Bending strengths of the alumina ceramics coated with and without $\beta$-tricalcium phosphate films. Spray-pyrolyses conditions: the CMP solution for $5 \mathrm{~h}$, and then the HAp solution for $5 \mathrm{~h}, 10 \mathrm{~h}$ and $15 \mathrm{~h}$. Heating conditions: $1200^{\circ} \mathrm{C}, 5 \mathrm{~h}$.

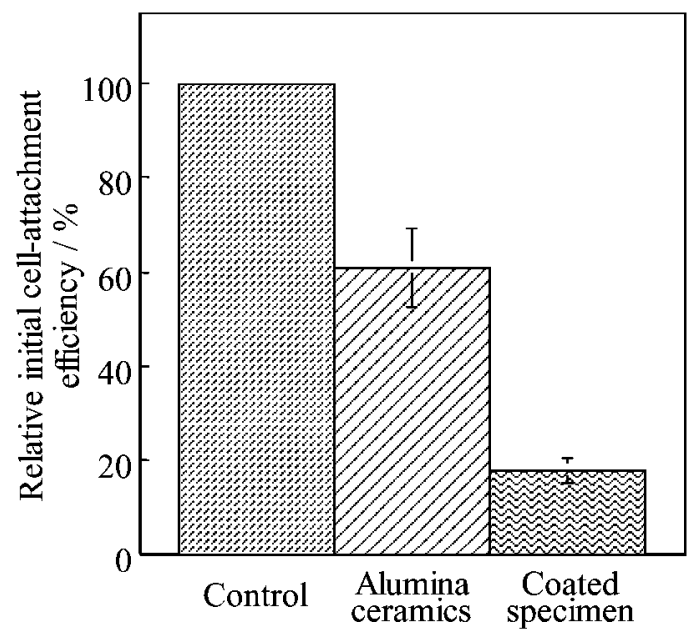

Fig. 6. Relative initial cell-attachment efficiency of the cells cultured on three kinds of specimens: (i) control (polystyrene), (ii) alumina ceramics, and (iii) coated specimens (alumina substrate coated with $\beta$-tricalcium phosphate).

$<0.05)$ on the basis of the ANOVA test.

The above difference in the relative initial cell-attachment efficiencies may be due to the surface roughness of the specimens. The surface of the coated specimen is much coarser than those of the alumina ceramics and the control; it may be difficult for the cells to adhere to the surface on the porous coated specimens.

The growth curves of the cells cultured on the three kinds of specimens are shown in Fig. 7. The cells on the coated specimens were proliferated in a similar manner to those of the control and the alumina ceramics. Nevertheless, there was a difference in the number of cells cultured for $1 \mathrm{~d}$ among the three kinds of specimens, because of the differences in the initial cell-attachment efficiencies as mentioned above. This result indicates that the proliferation rate of the cells cultured on the coated specimen is a match for the control and the alumina ceramics. Such coated specimens are expected to have

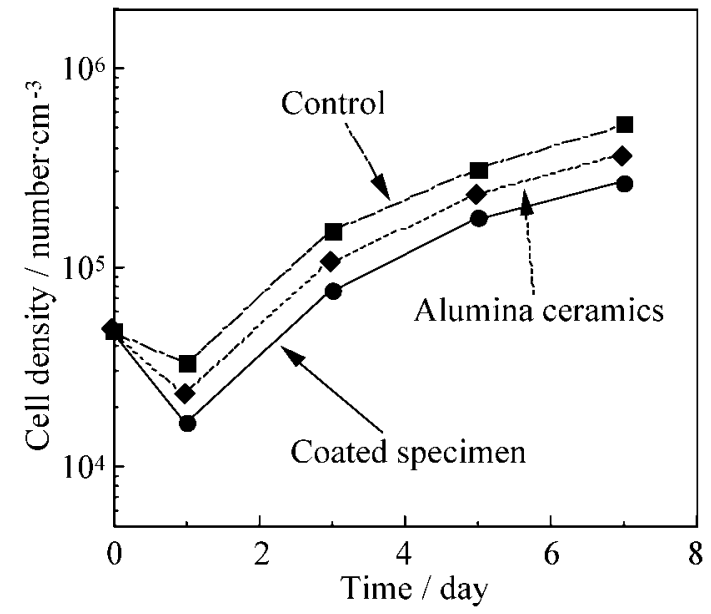

Fig. 7. Growth curves of cells cultured on three kinds of specimens: (i) control (polystyrene), (ii) alumina ceramics and (iii) coated specimens.

good cell proliferation similar to the control and the alumina ceramics.

Figure 8 shows the morphology of the cells cultured on the alumina ceramics and the coated specimens for 1 and $7 \mathrm{~d}$. The cells were fully attached to both specimens in the case of $1 \mathrm{~d}$. The cells on the alumina ceramics especially formed pseudopodium to spread on the specimen surface. In the case of the cells cultured for $7 \mathrm{~d}$, the cells on the coated and uncoated alumina ceramics fully spread and their cell densities attained nearly the confluent, as well as in the case of the control. SEM observation reveals that the present coated specimen has a good cellular response on the cell morphology as well as the alumina ceramics.

Figure 9 shows the ALP activity of cells cultured for $17 \mathrm{~d}$ on the three kinds of specimens. The ALP activity normalized for the DNA assay was measured in order to examine the differentiation into osteoblasts of the MC3T3-E1 cell line. These values on the three kinds of specimens were $79.9 \pm 13,86.3 \pm$ 19 and $150.0 \pm 16 \mathrm{mIU} /\left(\mathrm{dm}^{3} \cdot \mu \mathrm{gDNA}\right)$, at $37^{\circ} \mathrm{C}$, respectively; the ALP activity of the coated specimen showed the highest value among the examined specimens. These results could be regarded as significant $(p<0.05)$ on the basis of the ANOVA.

Osteoblasts produce specific proteins as their makers in accordance with the differentiation stages of the osteoblast; ${ }^{28)}$ for examples, collagen (type I) in the early stage, ALP in the early to intermediate stages, osteopontin (OP) in the intermediate stage, bone sialoprotein (BSP) in the late stage, and osteocalcin (OC) in the latest stage. Thus, ALP is a differentiation marker of osteoblasts from the early to intermediate stages. ${ }^{29)}$ The ALP activity of the present coated specimen is significantly higher than that of the uncoated alumina ceramics. Thus, we can conclude that the present porous films supply alumina ceramics with the specific ability to induce the differentiation of osteoblasts.

Thus, the $\beta$-TCP films employed in this investigation proved to have excellent biocompatibility, judging from the proliferation and ALP activity for the cells cultured on the three kinds of specimens. Further, the porous structure of the resulting films may enable the newly formed bone to integrate into the pores in the films, which will, in turn, make the coating materials bind more strongly with the host bones. 


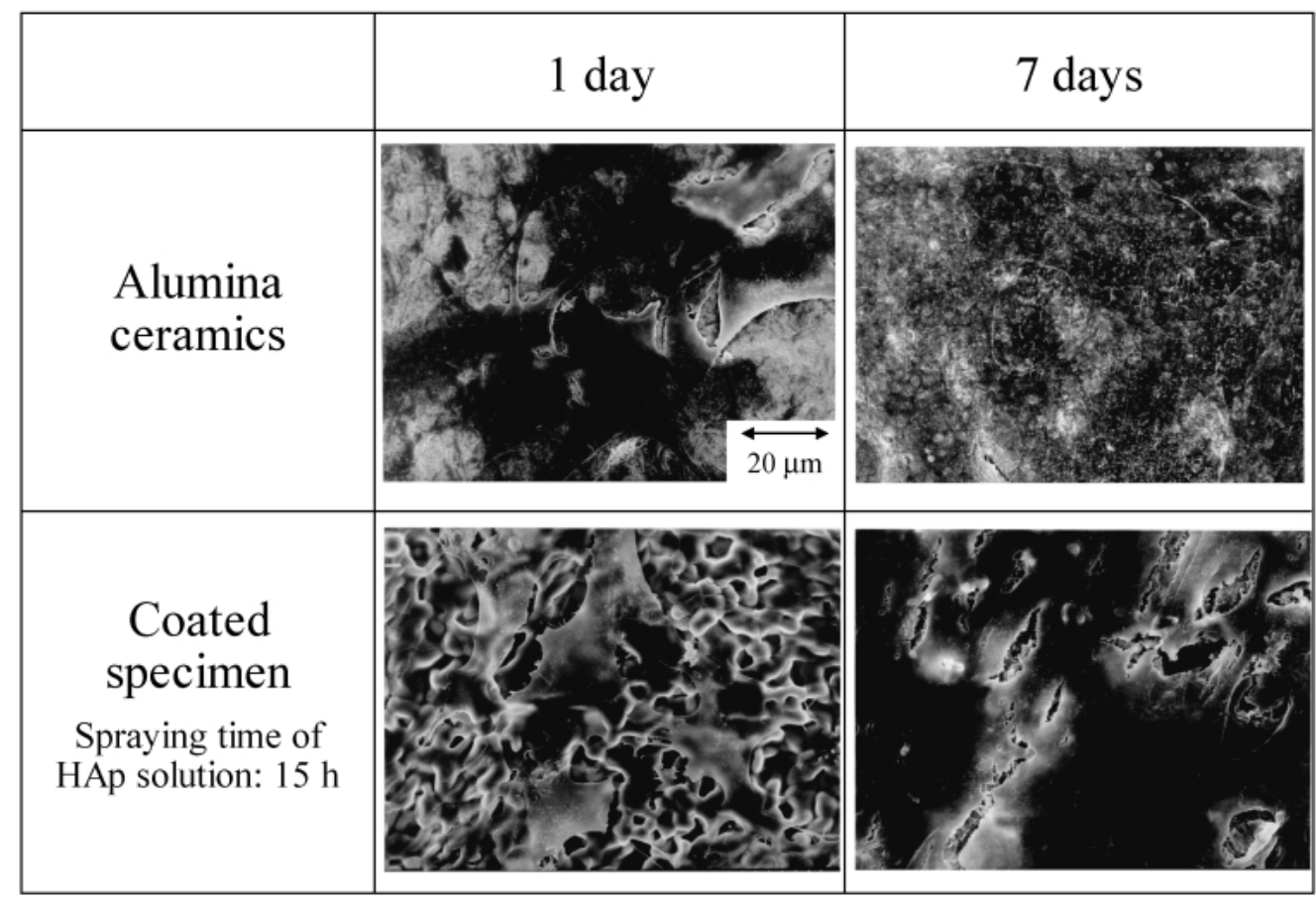

Fig. 8. Morphologies of the cells cultured on the coated specimens for 1 and $7 \mathrm{~d}$, together with those of the alumina ceramics.

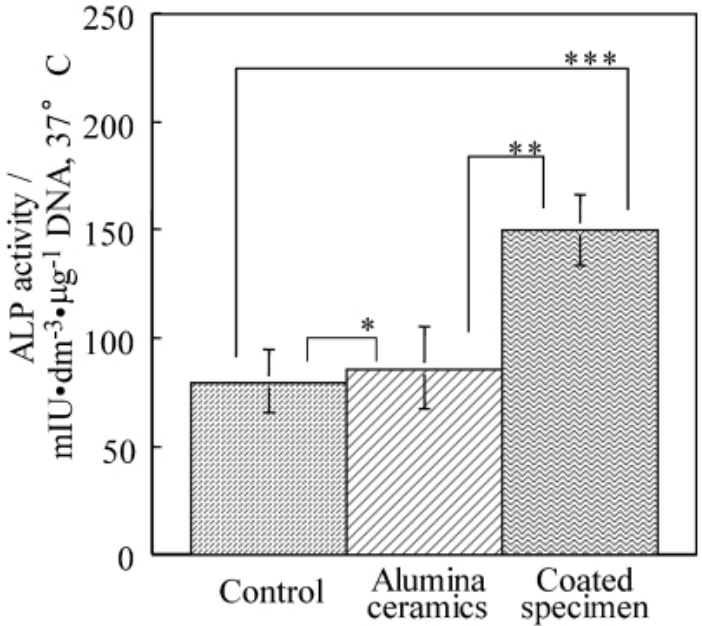

Fig. 9. Alkaline phosphatase (ALP) activity of the cells cultured for $17 \mathrm{~d}$ on the three kinds of specimens: control, alumina ceramics and coated specimen. The ALP activities were normalized for the DNA assay in the cells. ${ }^{*}: p>0.05,{ }^{* *}: p<0.05,{ }^{* * *}: p<0.05$.

\section{Conclusions}

Porous calcium-phosphate films were formed on alumina ceramics by a spray-pyrolysis technique. The crystalline phase of the resulting films was mainly $\beta$-TCP. The films were porous and $\sim 30 \mu \mathrm{m}$ thick. The films were still present on the substrate after a tape test. Such structure of the porous films enables the newly formed bone to integrate into the pores, which will make the coating materials bind strongly with the host bones. The examination of the biocompatibility using the MC3T3-E1 cells as an osteoblast model revealed that the cells on the alumina ceramics coated with $\beta$-TCP (coated specimen) proliferated in a similar manner to the case of the control (polystyrene) and the alumina ceramics. The ALP of the cells cultured on the coated specimen for $17 \mathrm{~d}$ showed the highest value among the examined specimens. Thus, the $\beta$ TCP films prepared in the present investigation proved to have excellent cellular responses with respect to the cell proliferation and differentiation.

\section{References}

1) Hench, L. L., J. Am. Ceram. Soc., Vol. 81, pp. 1705-1728 (1998).

2) Kanazawa, T., Umegaki, T., Monma, H. and Yamashita, K., Gypsum \& Lime, No. 210, pp. 261-273 (1987).

3) Wen, H. B., de Wijn, J. R., Cui, F. Z. and de Groot, K., $J$. Biomed. Mater. Res., Vol. 41, pp. 227-236 (1998).

4) Weng, W. and Baptista, J. L., J. Materi. Sci.: Mater. Med., Vol 9, pp. 159-163 (1998).

5) Hasegawa, A., Kameyama, Y., Motoe, A., Ueda, M., Akashi, K. and Fukuda, K., J. Ceram. Soc. Japan, Vol. 100, pp. 377-381 (1992).

6) Yamashita, K., Arashi, T., Kitagaki, K., Yamada, S. and Umegaki, T., J. Am. Ceram. Soc., Vol. 77, pp. 2401-2407 (1994).

7) Yamashita, K., Yonehara, E., Ding, X., Nagai, M., Umegaki, T. and Matsuda, M., J. Biomed. Mater. Res. (Appl. Biomater.), Vol. 43, pp. 46-53 (1998).

8) Abe, Y., Kokubo, T. and Yamamuro, T., J. Mater. Sci: Mater. Med., Vol. 1, pp. 233-238 (1990).

9) de Groot, K., Geesink, R., Klein, C. P. A. T. and Serekian, P., J. Biomed. Mater. Res., Vol. 21, pp. 1375-1381 (1987).

10) Kawamoto, Y., Yokogawa, Y., Toriyama, M., Kawamura, S. and Suzuki, T., J. Ceram. Soc. Japan (Seramikkusu Ronbunshi), Vol. 99, pp. 19-22 (1991).

11) Aizawa, M., Itatani, K., Howell, F. S., Kishioka, A. and Kinoshita, M., J. Ceram. Soc. Japan, Vol. 102, pp. 732-736 (1994).

12) Aizawa, M., Yamamoto, T., Itatani, K., Suemasu, H., Nozue, A. and Okada, I., Phosphorus Res. Bull., Vol. 10, pp. 283-288 (1999).

13) Aizawa, M., Yamamoto, T., Itatani, K., Suemasu, H., Nozue, A. and Okada, I., Key Engineer. Mater., Vol. 192-195, pp. 103-106 (2001). 
14) Aizawa, M., Itatani, K., Howell, F. S., Kishioka, A. and Kinoshita, M., J. Mater. Sci., Vol. 30, pp. 4936-4945 (1995).

15) Aizawa, M., Phosphorus Res. Bull., Vol. 11, pp. 19-24 (2000).

16) Nishine, W., Aizawa, M., Nawa, M., Itatani, K., Suemasu, H., Nozue, A. and Okada, I., Key Engineer. Mater., Vol. 218-220, pp. 213-216 (2002).

17) Aizawa, M. and Itatani, K., Hyoumen (Surfaces), Vol. 36, pp. 676-686 (1998).

18) Sudo, H., Kodama, H., Amagai, Y., Yamamoto, S. and Kasai, S., J. Cell Biol., Vol. 96, pp. 191-198 (1983).

19) Okada, M., Ceramics Japan, Vol. 25, pp. 320-326 (1990) [in Japanese].

20) Iijima, K., Itakura, Y., Ohno, T., Kodama, H., Amagai, Y., Sudo, H. and Yamamoto, S., Jpn. J. Oral. Biol., Vol. 28, pp. 170-176 (1986)

21) Bessey, O. A., Lowry, O. H. and Brock, M. J., J. Biol. Chem.,
Vol. 164, pp. 321-329 (1946).

22) Fix, W., Heymann, H. and Heinke, R., J. Am. Ceram. Soc., Vol. 52, pp. 346-347 (1969).

23) Mackay, A. L., Acta Cryst., Vol. 6, pp. 743-744 (1953).

24) Monma, H. and Kanazawa, T., J. Ceram. Soc. Japan (YogyoKyokai-Shi), Vol. 86, pp. 378-380 (1978).

25) Aizawa, M., Itatani, K., Miyamoto, Y., Kishioka, A. and Kinoshita, M., Gypsum \& Lime, No. 237, pp. 22-30 (1992).

26) Aizawa, M., Hanazawa, T., Itatani, K., Howell, F. S. and Kishioka, A., J. Mater. Sci., Vol. 34, pp. 2865-2873 (1999).

27) Klawittar, J. J., J. Biomed. Mater. Res., Vol. 2, pp. 161-229 (1971).

28) Ehara, A., Ogata, K., Imazato, S., Ebisu, S., Nakano, T. and Umakoshi, Y., Biomater., Vol. 24, pp. 831-836 (2003).

29) Ogushi, H., Okumura, M., Yoshikawa, T. and Tamai, S., J. Jpn. Soc. Biomater., Vol. 12, pp. 22-29 (1994). 